\title{
A Review Study of Psychometric Functioning of a Picture Scale to Assess Joy in Childhood
}

\author{
Laura Beatriz Oros ${ }^{1,2}$, María Cristina Richaud de Minzi ${ }^{3}$ \\ ${ }^{1}$ Institute of Scientific Research, University of La Cuenca del Plata, National Council of Scientific and Technical \\ Research (CONICET), Buenos Aires, Argentina \\ ${ }^{2}$ River Plate Adventist University, Superior Adventist Institute of Misiones, Misiones, Argentina \\ ${ }^{3}$ Interdisciplinary Center of Mathematical and Experimental Psychology Research, National Council of Scientific \\ and Technical Research (CONICET), Buenos Aires, Argentina \\ Email: lauraorosb@gmail.com
}

Received 26 January 2015; accepted 10 February 2015; published 12 February 2015

Copyright (C) 2015 by authors and Scientific Research Publishing Inc.

This work is licensed under the Creative Commons Attribution International License (CC BY).

http://creativecommons.org/licenses/by/4.0/

(c) () 0pen Access

\section{Abstract}

The early emergence of emotional understanding by means of facial expressions allows the assessment of basic emotions from young ages through pictures or photographs of human faces. This evaluation strategy allows children, with limited language to reveal feelings that neither investigators nor clinicians would be able to obtain verbally. The present work presents a non-verbal activity aimed at testing children's joy. It is based on a visual analogue scale integrated by seven pictures of infant facial expressions. This scale has the advantage of presenting an animated design, more friendly and appealing than simplified face scales. Its psychometric functioning, revised from different studies, demonstrates that it is a reliable and valid alternative to analyze the experience of joy in small children.

\section{Keywords}

Positive Emotions, Joy, Assessment, Children

\section{Introduction}

The emotions are complex functional states that derive from the psychological interpretation of certain stimuli and produce changes in the different systems of the organism (Bloch, 2008; Frijda, Manstead, \& Bem, 2000; Lazarus, 2000). At a cognitive level, an essential experience (feeling) is produced, allowing the subject to recognize and differentiate his own affective state (I am glad, I feel sad, etc.); at a biological level, neurophysiologic and biochemical changes emerge; and at a social level, neuromuscular-expressive changes become evident. 
These non-verbal expressions constitute a powerful means of communication of the individual's own emotional state (Garrido Gutiérrez, 2000).

According to Ekman (1973) there are six basic emotions (joy, sadness, anger, fear, disgust and surprise) that form the basis of the other socio-affective emotions, enable the individual's adaptation to the environment and have a particular connotation, very different to the rest. These basic emotions are associated with specific facial expressions recognized in different cultures, so that they have been assigned the quality of being universal or innate. Although this characterization has been questioned by some authors, it continued to receive strong support due to the empirical evidence behind (Garrido Gutiérrez, 2000).

Among these basic emotions, only joy appears as a clearly positive one. This emotional state is characterized by an intense feeling of pleasure and delight, usually caused by the occurrence of desirable events (David, Herring, Burleson, Roberts, \& Devine, 2011; Lazarus, 2000). According to Fredrickson, joy has the ability to increase the variety of thoughts and actions in response to a stimulus that motivates the subject to overcome his own limits and be creative. Besides, it also works in the construction of other social, intellectual, psychological and even physical resources that sustain resilience (Fredrickson, 1998, 2004).

Joy gains significant interest in the periods of infancy and childhood, as it is closely related to the urge to play, which in turn promotes physical and socio-cognitive skills such as exploration and invention (Fredrickson, 2001). In addition, laughter emerges as an inherent part of this process; it functions as a sign of openness to new, friendly interactions that extend social and affective resources (Fredrickson \& Cohn, 2008) probably through "emotional contagion". In line with this, a study carried out with children showed that joy decreases the probability of being rejected or excluded by their group of peers (Giqueaux \& Oros, 2008). Therefore, when well regulated, joy could be considered as a fundamental human strength that generates multiple interrelated benefits (Fredrickson, 2001). Surprisingly, despite its significance, this emotion has been little analyzed scientifically in child populations. Further research is needed to provide empirical evidence about its relationship with other important variables of development, as well as intervention programs that promote its strengthening from young ages.

The review by Platt, Hofmann, Ruch and Proyer (2013) demonstrates that so far there is no single classification and theoretically shared by all researchers about the different existing positive emotions. However, it seems that joy is the positive emotion par excellence, as it appears without exception, in every proposal for the evaluation and study of positive affect. This may be because-as it is a basic emotion-it is associated with a particular and universally recognized facial configuration, while the expression of other pleasant emotions could be less specific, and therefore, more difficult to distinguish (e.g. pride, enthusiasm, and gratitude).

The facial expression, mainly in the regions of the mouth and eyes, represents one of the main means of emotional communication, among other indicators such as tone of voice, posture, gestures, personal appearance and way of walking (Martín, Avero, \& Gutiérrez Calvo, 2012). It has been scientifically proved that through the physical properties of the face it is possible to infer, with a high degree of certainty, the emotional state underlying these expressions, even if the observed subject and the observer belong to completely different cultures (Ekman, 1973). In other words, from the emotional expression, the emotional experience can be glimpsed.

As regards joy, the smile is its characteristic facial configuration; however, as its intensity increases, laughter usually appears, which can be even accompanied by body movements such as clapping or jumping. These nonverbal cues were identified early by Darwin and later codified by Ekman and contributors (Matsumoto, Keltner, Shiota, O'sullivan, \& Frank, 2008). When the smile is genuine (called Duchenne smile or pleasant smile), it follows a muscular patter involving, among other aspects, the action of the zygomaticus major muscle (placed on the cheek) and the orbicular muscle, being symmetrical to both sides of the face (Frank \& Ekman, 1993; Ekman, 2003; Ekman, Hager, \& Friesen, 1981; Niedenthal, Mermillod, Maringer, \& Hess, 2010). Although there are some subtle differences between a genuine smile and a fake one, it has been demonstrated that even children aged 7 years have the ability to adequately differentiate them (Gosselin, Perron, \& Maassarania, 2009).

Although the contribution of the upper (eyes and eyebrows) and lower (lips and cheeks) parts of the face are equally important to attain the configuration of joy, experimental studies show that both, children and adults prioritize the observation of the lips so as to differentiate this emotional expression from others (Fox, 2004, cited by Levav, 2005; Karayanidis, Kelly, Chapman, Mayes, \& Johnston, 2009).

Emotional understanding involves a set of skills that begin to develop in early infancy and that are influence by individual and contextual differences (Albanese, De Stasio, Di Chiacchio, Fiorilli, \& Pons, 2010; Pons \& Harris, 2005; Pons, Lawson, Harris, \& de Rosnay, 2003), increasing progressively with age (MacDonald \& Kirk- 
patrick, 1996; Gao \& Maurer, 2009).

Pons, de Rosnay and Harris (2004) suggest a hierarchical evolutionary model of emotional understanding consisting of 9 components, being the first one precisely facial recognition. Around the age of 3 or 4 years, children are able to recognize and name specific emotions on the basis of real or animated facial expressions (see also Stifter \& Fox, 1986). This state is followed by the following eight states: 1) understanding external causes of emotion; 2) understanding the link between desire and emotion; 3) understanding the link between belief and emotion; 4) understanding the influence of memory on emotion; 5) understanding emotion regulation; 6) understanding that it is possible to hide or conceal emotions; 7) understanding mixed emotions (the emergence of multiple emotional reactions, even contradictory); and 8) understanding moral emotions.

These nine components can be further grouped into three big successive stages: The outer one, which covers facial recognition, memory influence and emotional causes; the mental one, which considers the impact of desires and beliefs on emotion and the distinction between real and fictitious emotions; and the reflective one, which uses more complex cognitive processes that allow to understand emotional regulation, morality and mixed emotions (Albanese et al., 2010).

\section{Taking Advantage of Face Recognition Ability to Assess Emotions}

The early emergence of emotional understanding through facial signs allows the assessment of basic emotions from early ages by means of pictures or photographs of human faces. This evaluation strategy enables children, with limited language or with difficulty in interpreting or executing verbal instructions to reveal feelings that investigators and clinician would not be able to obtain verbally (MacDonald \& Kirkpatrick, 1996; Widen \& Russell, 2008).

Happiness is one of the emotions more accurately recognized by pre-school children and those in their first two years of primary school (Gao \& Maurer, 2010; Székely et al., 2011), and it is indifferent to use real photographs or schematic pictures for its recognition as both visual stimuli produce answers with the same degree of accuracy (MacDonald \& Kirkpatrick, 1996). MacDonald \& Kirkpatrick (1996) concluded that the use of schematic pictures provides a viable alternative to the use of photographs when working with young children, for they have the advantage of reducing the influence of irrelevant elements, as the abundance of details that characterized photographs (as regards gender or other characteristics of the real model) could distract the examinees at the moment of focusing their attention on key facial signs. Though being a reasonable assessment, it has to be considered that children find unattractive too simple and schematic scales in comparison to those that present more friendly designs such as those resembling cartoons (Chambers, Giesbrecht, Craig, Bennett, \& Huntsman, 1999). Therefore, to generate innovative scales that include details and characteristics in order to captivate the attention of children and at the same time that may provide valid and reliable measures represents a real challenge.

MacDonald and Kirkpatrick (1996) suggest that in order to maximize the correct interpretation of facial expressions is advisable to avoid unnecessary contextual information, as well as verbal labels associated with the pictures or introductory stories. Both the instruction and the task should be as simple as possible.

Face scales evaluate emotion from a single item and usually offer between five and seven response options. These options are represented by real faces or pictures that combine different expressive patterns in order to reflect particular emotional states. For such contributions, the position of the eyebrows, eyes, nose, mouth and cheeks are considered. The examinees should mark the option that best reflect their affective condition. Different investigations have concluded that visual scales have a correct psychometric functioning and that are useful in predicting behavior. For instance, Holder, Coleman and Singh (2011) used three different methods to test happiness in children from India aged 7 to 14 years; the authors found that the face scale showed concurrent validity with the other two methods of psychometric adjustment (the Oxford Happiness Questionnaire, by Hills \& Argyle, 2002; and the Subjective Happiness Scale by Lyubomirsky \& Lepper, 1999) without incurring in multicollinearity. Likewise, the authors found evidence as regards construct validity when proving the hypothesis that certain temperamental characteristics of children, such as the level of activity and low shyness, predicted the experience of happiness assessed with this method. Finally, they noted that there exists good agreement between children's self-reports and parents' reports about their children's happiness when using the face scale, though these last results do not match those reported by Chambers, Giesbrecht, Craig, Bennett and Huntsman (1999) when using pain face scales. 
In turn, Jiménez Morón and Saiz Ruiz (1998) used a face scale to assess feelings of depression in psychiatric patients of poor cultural level, confirming that the score obtained with this method correlated significantly with the scores obtained by the same group of patients in both the depression rating scale of Montgomery and Asberg (1979) and the Global Clinical Impression. Face pain scales have also shown adequate levels of reliability and good concurrent validity in adult populations with cognitive impairment (Benaim et al., 2007), and they have been preferred by the examinees over other methods (Ware, Epps, Herr, \& Packard, 2006). With regard to child populations, Wong and Baker (1988) found that the face pain scale was as reliable and valid as other methods but with the advantage of being preferred by children and adolescents from 3 to 18 years old compared to other scales of a single item (verbal label scales, numeric scales, graphic scales and choice tasks and manipulation of objects and colors). Similar results have been reported by Miró and Huguet (2004) who evaluated pain in a sample of Spanish children and adolescents. Chambers et al. (1999) examined the opinions of a group of children between 5 and 12 years old, and those of their parents to determine the degree of preference for different versions of face pain scales. The authors compared five scales that differed in format from simple schematic pictures, though animated pictures, to more realistic infant portraits. Children and parents dismissed the simplest and the most complex pictures, agreeing that the most attractive and friendly version was the one that resembled an animated design.

Based on this background, the present work aimed at proposing a new visual scale to evaluate children's joy, including increased complexity of details than schematic designs normally used in face scales, in order to offer an even more attractive and friendly device for child populations without sacrificing aspects that contribute to its validity and reliability. It is considered that this research would provide relevant information, as the functioning and utility of face scales have been extensively studied in relation to the assessment of negative emotions and pain, while evidence as regards its validity and reliability for exploring positive emotions is insufficient. Thus, the evaluation of children's joy remains a challenge for modern psychology. Setting parameters or baselines of this positive emotion will ease its inclusion in new theoretical explanatory models contributing to clarify its relationship with other variables during childhood. Besides, it will allow judging the evolution and progress of the positive emotional experience as a function of the socio-affective intervention, another great contemporary challenge.

\section{Characterization of the Visual Analog Scale of Joy (VAS-Joy)}

The visual analog scale of joy (VAS-joy) consists of a sequence of infant facial expressions that resemble cartoons. It is illustrated in full color; it shows faces in the context of shoulder posture and includes basic details such as hair and eyelashes. These features make the pictures relatively more realistic and similar to the examinee in comparison to traditional schematic ones, but limit their use to Caucasian children (as drawings represent children with fair skin), being necessary their adaptation for cross-cultural use.

Facial expressions are horizontally arranged from the most joyful to the saddest one, including a neutral expression. Children are requested to point to the expression that best reflects their mood state in terms of joysadness, on a regular basis or at the time of doing the task, depending on the intention to evaluate joy as a feature or as a state. There is a version for girls and one for boys. For statistical purposes, each picture was assigned with a numerical value from 1 (very sad) to 7 (cheerful); however, these values are not visible to children to avoid their effect on the choice of the faces. The images measure approximately $4 \mathrm{~cm}$ high and $3 \mathrm{~cm}$ wide, separated by a distance of $1.5 \mathrm{~cm}$.

A preliminary version of this scale was first used to ease the following problems that produced the use of verbal tests to assess positive emotions in young children with low cognitive stimulation (Oros, 2008): 1) limitations to elaborate their answers; 2) acquiescence; 3) automatic answers; 4) difficulty to keep attention making the diagnostic task a slow and expensive process. Due to these issues, the decision was to use the visual analog scale of joy that was able to awaken children's interest and provoke a larger quantity of valid responses in less time. Besides, this visual-analog method managed to avoid social desirability showing low and non significant correlations $(\mathrm{r}=.01 ; p=.95)$ with a test that assess this tendency (Lemos, 2005). On the other hand, the responses enabled to differentiate among those children with high and low joy frequency $(\mathrm{t}=-13.77 ; p<.001)$, a decisive criterion to use step tests (Nogales, 1997). In summary, the use of this new technique significantly improved the quality of children's answers and reduced test time.

From this first experience, cartoons were digitally improved and used in different Argentine investigations. 
Following, some information as regards its psychometric functioning is provided.

\subsection{Evidence of Its Psychometric Functioning}

The VAS-joy was used with distinct purposes in different scientific studies. Statistical procedures performed with different samples of Argentine children show the psychometric goodness of the scale. Below, the arguments in favor of its validity and reliability from a review of these investigations are presented.

\subsubsection{Evidence of Construct Validity}

Construct validity refers to the body of evidence proving that the observable behaviors of the test are indicators of the hypothetical construct that is intended to be evaluated (Martínez Arias, 1995), thus integrating the psychometric and theoretical notions (Richaud de Minzi, 2005). According to this definition, the validity of a specific method cannot be proved by means of a single coefficient but requires various signs of evidence (Martínez Arias, 1995). Following, multiple checks on different lines of construct validity are presented: 1) validity based on the implementation of an experimental design; 2) nomological validity; 3) convergent validity; 4) discriminate validity.

\subsubsection{Validity Based on the Implementation of an Experimental Design}

This type of validation is used when the theory specifies the possibility of changes in the position of the construct from certain interventions (Martínez Arias, 1995). In the case of positive emotions, it has been demonstrated that despite its strong genetic dependence, personal and environmental initiatives can increase them to each individual's fullest potential (Lyubomirsky, 2007; Watson, 2005). Studies about happiness have indicated that approximately $40 \%$ of the positive emotional experience is determine by those cognitive, behavioral and volitive actions that people perform with certain personal effort in order to increase their positive emotional experience. Therefore, as Fredrickson (2000) expresses, it is possible to believe that positive emotions, within certain limits, can be purposely cultivated and strengthened by means of the systematic implementation of adequate strategies. From this perspective, it may be hypothesized that joy scores would increase as a result of an intervention to stimulate such emotions.

The Vas-joy was used repeatedly before and after implementing programs stimulating positive emotions with different groups of children aged 4 to 9 years (Oros, 2006, 2009). Results indicated that positive changes actually occurred in the children's experience of joy as a result of the implementation of the program, and that the scale was sensitive enough so as to detect those changes, even in the case of younger children $(F(1 ; 61)=5.87 ; p=.02)$ (Oros, 2009). Besides, the results obtained by means of the Vas-joy were contrasted with the observations of these children's teachers, concluding that children were certainly more animated, more satisfied and happier in a general sense (Oros, 2006; Oros, Manucci, \& Richaud de Minzi, 2011).

\subsubsection{Evidence of Nomological Validity}

According to Cronbach and Meehl (1955) and Campbell (1960) there is a possibility to validate a test by means of the joint use of another test that assess a different construct but theoretically related. The test credibility increases when its use enables the confirmation of the predicted relationship, i.e. the hypothesized relationship between both evaluated constructs.

The research carried out by Schulz Begle (2012) provides data for an initial approximation to the nomological vality of the VAS-joy. Starting from a previous theoretical network (Cassidy \& Asher, 1992; Chen et al., 2002; Richaud de Minzi et al., in press; Merrell \& Gimpel, 1998; Michelson et al., 1987; Segrin \& Taylor, 2007; Vaughan Sallquist et al. 2009), the author analyzed the hypothesis that children's social abilities were related to the experience of positive emotions, among which, the assessment of joy was included. Her results were calculated on a sample of 607 Argentine children aged 8 to 12 years, using the Spanish translation of the Matson Evaluation of Social Skills with Youngsters (Trianes et al., 2002; original scale in Matson et al., 1983). Those results referring only to the VAS-joy scores showed significant and positive relationships with social performance in general and with assertiveness in particular, and significant and negative connections with aggressiveness and social anxiety. The direction of these correlations showed a pattern consistent with what has been theoretically hypothesized, as the most socially adept children tended to experience more joy than anxious, arrogant or aggressive ones. However, the degree of connection among variables was weak suggesting that the link 
between social skills and joy can be rather indirect, having moderators that absorb most of the variance explained. Similar low but significant levels were obtained in the same study when relating the social skills with another method of joy assessment (PANAS-C) (Schulz Begle, Lemos, \& Richaud de Minzi, 2009), which would confirm that the low correlation obtained with the VAS-joy scores is not due to particular characteristics of this method of assessment, but actually to other explanatory factors that will be analysed in the discussion (see Table 1). However, these results should be considered with caution given the known effect of the sample size on significance levels.

Otherwise, a more recent study (Oros, Vargas Rubilar, \& Krumm, 2014) examined the relationship between the positive emotional experience of children and parental rearing patterns hypothesizing that the latter could act as predictors of the former. This study included 226 children between 6 and 12 years old, in equal share by gender. Parenting practices were assessed by children's self-reports on their perceptions about their relationship with their parents (Richaud de Minzi, 2007). It was concluded that a hostile parental control undermines children's joy $(\beta=-.21, p=.02)$, whereas a normal one tends to strengthen it $(\beta=.21, p=.01)(\mathrm{r} 2=.08)$.

In the same study, the relationship between the attachment bond with parents and the experience of positive emotions (joy, personal satisfaction, gratitude and sympathy) in a sample of 105 children with an average age of approximately 9 years was analyzed. The attachment bond was assessed with the Argentine version of the Kerns Security Scale (Kerns, Klepac, \& Cole, 1996) by Richaud de Minzi, Sacchi, \& Moreno (2001). Results demonstrated that maternal availability would play a predictive role of the values of joy provided by the VAS-joy ( $\beta$ $=.26, p=.04, \mathrm{r} 2=.09$ ), as exposed in the main theoretical model of attachment (Bowlby, 2009).

\subsubsection{Evidence of Convergent Validity}

The convergent validity of the VAS-joy was studied correlating their scores with those of the joy items included in the Child Positive Emotions Questionnaire (CIEP) (Oros, 2014). This study involved 53 boys $(\mathrm{n}=21)$ and girls $(n=32)$ who were in 4 th grade of primary school. It was decided to work with this school group because at this age (average 9 years), children already master with ease the processes of interpretation of instructions, reading and writing in order to respond individually the verbal self-report scale (CIEP). Pearson's bivariate correlation was calculated between the two measures, finding a positive and significant relationship between them $(\mathrm{r}=.72, p<.001)($ Oros, 2013).

On the other hand, a positive and significant correlation, though lower than the previous one, was also found between the VAS-joy and the PANAS-C-Arg subscale for positive affect developed by Schulz Begle, Lemos and Richaud of Minzi (2009) $(r=.30, p=.01)$. Participants were 216 schoolchildren of both genders aged 8 to 12 years. The PANAS-C-Arg items that correlated most significantly with joy were happy $(\mathrm{r}=.27, p<.001)$; full of energy $(\mathrm{r}=.26, p<.001)$; content $(\mathrm{r}=.22, p<.001)$; charmed/amazed $(\mathrm{r}=.23, p<.001)$ and lively, bold $(\mathrm{r}=.30, p<.001)$. In addition, the VAS-joy correlated significantly and inversely with the items: discouraged/ distressed $(\mathrm{r}=.18, p=.01)$ and disgust/jaded $(\mathrm{r}=-.15, p=.03)$ (Oros, 2013). The observed correlations occur in the theoretically expected direction and support the convergence between methods. The fact that they tend to be relatively low may reflect the specificity of the scales to assess emotion as a state and as a trait, respectively. Note that the PANAS instructs children to select those emotions experienced in the short term. In contrast, the VAS-joy in this case requested children to indicate how they usually felt.

Finally, it is worthy to note that the answers of 367 children aged 8 to 12 years were compared with the answers of their parents by means of the VAS-joy. Parents were required to indicate the emotional expression that best reflects the way their children regularly felt. A t test for related samples showed that there is no significant differences between the way children value their own emotional experience and that observed by their parents ( $\mathrm{t}$ $(366)=-.43 ; p=.67)$. The bivariate correlation of Pearson between both evaluations was moderate and significant $(\mathrm{r}=.41 ; p<.001)$ (Oros, 2013) getting close to values reported in other similar studies (Holder, Coleman, \& Singh, 2011).

Table 1. Bivariate correlations between scales of joy and social skills in children.

\begin{tabular}{cccccc}
\hline \multirow{2}{*}{ Scales of Joy } & \multicolumn{3}{c}{ Social Skills } \\
\cline { 2 - 5 } & General Social Performance & Asertiveness & Agressiveness & Arrogance & Social Anxiety \\
\hline VAS-Joy & $.15^{* * a}$ & $.14^{* *}$ & $-.12^{* *}$ & -.03 & $-.14^{* *}$ \\
PANAS (Joy) & $.22^{* *}$ & $.19^{* *}$ & $-.15^{*}$ & $-.15^{*}$ & $-.14^{*}$ \\
\hline
\end{tabular}

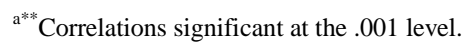




\subsubsection{Evidence of Stability}

Sixty-two children aged 4 to 7 years were allowed by their parents to answer the VAS-joy on two different occasions, with an interval of one week between the first and the second administration. The test-retest results indicated acceptable stability scores $(r=.81, p<.001)$. The $t$ test for related samples confirmed the absence of significant differences between the answers given by children in both instances of assessment (t $(61)=.92, p$ $=.36)($ Oros, 2013).

\section{Discussion and Conclusion}

Joy is a human strength that functions as a social mobilizer enriching and encouraging meaningful exchanges with others. This emotion has important physical, psychological and social impact that protect and promote individual well-being, so that it should become a priority focus of attention in the field of positive psychology. However, studies focusing on its analysis, especially in child populations, are remarkably scarce. One reason may be the fact that not enough efforts have been made to generate instruments for its measurement.

The present study has aimed at providing information on the utility and psychometric function of a nonverbal alternative to assess joy in children. Facial scales have a wide range of uses, being particularly appropriate to collect information from preschoolers with difficulty in reading and writing, who speak a language or dialect different to that of the evaluator, or simply refuse to answer lengthy questionnaires. Besides, due to its short length, these scales are particularly recommended for working in the school setting, when teachers, parents or evaluators are required to report on their students' emotional experience using a single item rather than a questionnaire or a grid of observation with multiple questions or indicators.

The VAS-joy is a facial scale that has the advantage of presenting an animated design, more friendly and attractive for young audiences than traditional schematic face scales. The studies included in this review (Schulz Begle, 2012; Oros, 2013, Oros, 2013; Oros, 2008, 2009; Oros et al., 2011) report that the features of this new design does not affect their psychometric goodness. On the contrary, it has become clear that the scores obtained by means of VAS-joy are reliable and valid and allow inferring, with a suitable degree of accuracy, young children's experience of joy. This accuracy is reflected in the coherence between the level of joy reported by children and what their parents and teachers percieve (Oros et al., 2011; Oros, 2013). Nevertheless, it would be interesting in future studies to provide an accurate measure of how far this scale is more attractive for children compared to other schematic scales. Children's interest could be assessed by monitoring their eye movements and facial expressions, and the amount of time they stop to observe the patterns of the different scales.

The study of construct validity based on the application of an experimental design has demonstrated, on the one hand, that positive emotional experiences can be encouraged and strengthened to each individual's fullest potential as theoretically postulated, (Lyubomirsky, 2007, Watson, 2005) and, on the other hand, that the VASjoy is sensitive enough to detect emotional changes that occur as a result of the interventions. Thus, being proved the hypothesis that specifies the possibility of changes in the construct, evidence in favor of the construct validity of the scale can be added.

Regarding nomological validity, it has been effectively noted that joy-VAS correlates significantly with other tests that assess theoretically related constructs. For example, it was found that joy would be related to children's social skills. Assertive children, who avoid using aggression in their relationships and do not have social anxiety, would have a greater predisposition to feel joyful. However, as the correlation coefficients are low (ranging between -.12 and .15) it may be hypothezized that there exists an indirect relationship between the variables, mediated by other social elements. In this sense, for instance, the number of close friends, the level of social acceptance and popularity and the adoption of significant roles within a group could be considered as immediate results of a good repertoire of social skills, as well as more direct drivers of positive emotional experience. In other words, socially skilled behavior would allow children to enjoy a more extensive network of close friends, to be more accepted among their peers and assume socially desirable roles that, in turn, would generate a direct increase of their joy and contentment. Although these new conjectures have bibliographic support (Delgado Egido \& Contreras, 2009; Denham, McKinley, Couchoud, \& Holt, 1990; Oros \& Greco, 2009), they should be further analyzed in future studies. As Schulz Begle (2009) mentions, those studies oriented towards promptly analyze the relationship between positive emotions and social skills in childhood are scarce; therefore, it becomes necessary to continue delving on this topic.

Other data that confer nomological validity to the scale are those related to the relationship of joy with mater- 
nal attachment and parenting practices. The reviewed studies confirmed the hypothesis that, during childhood, joy depends largely on children's perception of maternal availability. During this evolutionary period, one of the most desirable and essential event to survival and well-being is the interaction with an accessible and responsive attachment figure in times of pain, fatigue, fear or confusion. No wonder, then, that when the attachment relationship works well and is characterized by a great deal of time and care given to children, it creates happiness, joy and personal security in the latter (Bowlby, 2009). Moreover, and as expected, it was found that a hostile parental control undermines the experience of joy in children while a normal one favors it. These results are also consistent with previous research showing that positive emotional experience depends on socio-environmental factors, mainly on family relationships, being the unbalanced parental control a real obstructive factor for social and emotional children's development (Baumrind, 1966; Betancourt Ocampo \& Andrade Palos, 2011; Richaud de Minzi, 2002; Oliva, 2006, Wang, Pomerantz, \& Chen, 2007).

Evidence of convergent validity of the scale was also found through its significant and theoretically expected correlation with other tests with proven psychometric adjustment, and stability of scores, by obtaining an adequate correlation between successive applications (test-retest).

For these reasons, it is considered that the VAS-joy is a reliable and valid alternative to use in child population, though with certain restrictions which are worth mentioning. First, its use is limited to children from Caucasian populations, being necessary the adaptation of its design to other populations with different facial features (e.g. Oriental children, African children, etc.). In addition, its use is restricted to the assessment of joy, not being recommended for the assessment of negative emotions or pain without prior analysis of its convenience. Specifically, regarding pain assessment, it has been suggested to avoid face scales that include smiley faces as absence of pain indicators, as they tend to bias the results making children to mark higher levels of pain than when neutral faces are used (Chambers et al., 1999).

\section{References}

Albanese, O., De Stasio, S., Di Chiacchio, C., Fiorilli, C., \& Pons, F. (2010). Emotion Comprehension: The Impact of NonVerbal Intelligence. The Journal of Genetic Psychology, 171, 101-115. http://dx.doi.org/10.1080/00221320903548084

Baumrind, D. (1966). Effects of Authoritative Parental Control on Child Behavior. Child Development, 37, 887-907. http://dx.doi.org/10.2307/1126611

Benaim, C., Froger, J., Cazottes, C., Gueben, D., Porte, M., Desnuelle, C., \& Pelissier, J. Y. (2007). Use of the Faces Pain Scale by Left and Right Hemispheric Stroke Patients. Pain, 128, 52-58. http://dx.doi.org/10.1016/j.pain.2006.08.029

Betancourt Ocampo, D. B., \& Andrade Palos, P. A. (2011). Control parental y problemas emocionales y de conducta en adolescentes [Parental Control and Emotional and Behavioral Problems in Adolescents]. Revista Colombiana de Psicología, 20, 27-41.

Bloch, S. (2008). Alba Emotion. Generación y modulación de las emociones desde la respiración. In S. Ferrer Ducau (Ed.), [Alba Emotion. Generation and modulation of emotions from breathing] Las emociones (pp. 161-180). Santiago de Chile: Mediterráneo.

Bowlby, J. (2009). Una base segura [A Secure Base]. Buenos Aires: Paidós.

Campbell, D. T. (1960). Recommendations for APA Test Standards Regarding Construct, Trait, or Discriminant Validity. American Psychologist, 15, 546. http://dx.doi.org/10.1037/h0048255

Cassidy, J. \& Asher, S. (1992). Loneliness and Peer Relations in Young Children. Child Development, 63, 350-365. http://dx.doi.org/10.2307/1131484

Chambers, C. T., Giesbrecht, K., Craig, K. D., Bennett, S. M., \& Huntsman, E. (1999). A Comparison of Faces Scales for the Measurement of Pediatric Pain: Children’s and Parents’ Ratings. Pain, 83, 25-35. http://dx.doi.org/10.1016/S0304-3959(99)00086-X

Chen, X., Liu, M., Rubin, K., Cen, G., \& Gao, X. (2002). Sociability and Prosocial Orientation as Predictors of Youth Adjustment: A Seven-Year Longitudinal Study in a Chinese Simple. International Journal of Behavioral Development, 26, 128-136. http://dx.doi.org/10.1080/01650250042000690

Cronbach, L. J., \& Meehl, P. E. (1955). Construct Validity in Psychological Tests. Psychological Bulletin, 52, $281-302$. http://dx.doi.org/10.1037/h0040957

Delgado Egido, B., \& Contreras, F. (2009). Desarrollo social y emocional [Social and Emotional Development]. In B. Delgado Egido (Coord.), Psicología del desarrollo. Vol. 2: Desde la infancia a la vejez [Developmental Psychology. Vol. 2: From Infancy to Old Age] (pp. 35-66). Madrid: McGraw-Hill.

Denham, S. A., McKinley, M., Couchoud, E. A., \& Holt, R. (1990). Emotional and Behavioral Predictors of Preschool Peer 
Ratings. Child Development, 61, 1145-1152. http://dx.doi.org/10.2307/1130882

David, R., Herring, D. R., Burleson, M. H., Roberts, N. A., \& Devine, M. J. (2011). Coherent with Laughter: Subjective Experience, Behavior, and Physiological Responses during Amusement and Joy. International Journal of Psychophysiology, 79, 211-218. http://dx.doi.org/10.1016/j.ijpsycho.2010.10.007

Ekman, P. (1973). Cross-Cultural Studies of Facial Expression. In P. Ekman (Ed.), Darwin and Facial Expression: A Century of Research in Review (pp. 169-222). New York: Academic Press.

Ekman, P. (2003). Emotions Revealed: Recognizing Faces and Feelings to Improve Communication and Emotional Life. New York: Times Books.

Ekman, P., Hager, J. C., \& Friesen, W. V. (1981). The Symmetry of Emotional and Deliberate Facial Actions. Psychophysiology, 18, 101-106. http://dx.doi.org/10.1111/j.1469-8986.1981.tb02919.x

Frank, M., \& Ekman, P. (1993). Not All Smiles Are Created Equal: The Differences between Enjoyment and Nonenjoyment Smiles. Humor, 6, 9-26. http://dx.doi.org/10.1515/humr.1993.6.1.9

Fredrickson, B. (1998). What Good Are Positive Emotions? Review of General Psychology, 2, 300-319. http://dx.doi.org/10.1037/1089-2680.2.3.300

Fredrickson, B. (2000). Cultivating Positive Emotions to Optimize Health and Well-Being. Prevention \& Treatment, 3. http://www.unc.edu/peplab/publications/cultivating.pdf http://dx.doi.org/10.1037/1522-3736.3.1.31a

Fredrickson, B. (2001). The Role of Positive Emotions in Positive Psychology: The Broaden-and-Build Theory of Positive Emotions. American Psychologist, 56, 218-226. http://dx.doi.org/10.1037/0003-066X.56.3.218

Fredrickson, B. (2004). The Broaden-and-Build Theory of Positive Emotions. Philosophical Transactions of the Royal Society B: Biological Sciences, 359, 1367-1377. http://dx.doi.org/10.1098/rstb.2004.1512

Fredrickson, B. L., \& Cohn, M. A. (2008). Positive Emotions. In M. Lewis, J. M. Haviland-Jones, \& L. F. Barrett (Eds.), Handbook of Emotions (pp. 777-796). New York: Guilford Press.

Frijda, N. H., Manstead, A. S. R., \& Bem, S. (2000). Emotions and Beliefs. How Feelings Influence Thoughts. Paris: Cambridge University Press. http://dx.doi.org/10.1017/CBO9780511659904

Gao, X., \& Maurer, D. (2009). Influence of Intensity on Children's Sensitivity to Happy, Sad, and Fearful Facial Expressions. Journal of Experimental Child Psychology, 102, 503-521. http://dx.doi.org/10.1016/j.jecp.2008.11.002

Gao, X., \& Maurer, D. (2010). A Happy Story: Developmental Changes in Children’s Sensitivity to Facial Expressions of Varying Intensities. Journal of Experimental Child Psychology, 107, 67-86. http://dx.doi.org/10.1016/j.jecp.2010.05.003

Garrido Gutiérrez, I. (2000). Psicología de la emoción [Psychology of Emotion]. Madrid: Síntesis.

Giqueaux, G., \& Oros, L. (2008). Las emociones positivas como facilitadoras de la sociabilidad infantil [Positive Emotions as Facilitators of Children's Sociability]. XII Congreso Nacional de Psicodiagnóstico, ADEIP, Buenos Aires.

Gosselin, P., Perron, M., \& Maassarania, R. (2009). Children's Ability to Distinguish between Enjoyment and Nonenjoyment Smiles. Infant and Child Development, 19, 297-312.

Hills, P., \& Argyle, M. (2002). The Oxford Happiness Questionnaire: A Compact Scale for the Measurement of Psychological Well-Being. Personality and Individual Differences, 33, 1073-1082. http://dx.doi.org/10.1016/S0191-8869(01)00213-6

Holder, M. D., Coleman, B., \& Singh, K. (2011). Temperament and Happiness in Children in India. Journal of Happiness Studies, 13, 261-274. http://dx.doi.org/10.1007/s10902-011-9262-x

Jiménez Morón, D., \& Saiz Ruiz, J. (1998). Una escala facial de depresión para poblaciones de bajo nivel cultural: Resultados preliminares en una muestra de pacientes psiquiátricos ambulatorios [A Depression Face Scale for Poorly Educated Populations: Preliminary Results in a Sample of Psychiatric Outpatients]. Revista Electrónica de Psiquiatría, 2. http://www.psiquiatria.com/psiquiatria/vol2num1/art_5.htm

Karayanidis, F., Kelly, M., Chapman, P., Mayes, A., \& Johnston, P. (2009). Facial Identity and Facial Expression Matching in 5-12-Year-Old Children and Adults. Infant and Child Development, 18, 404-421. http://dx.doi.org/10.1002/icd.615

Kerns, K. A., Klepar, L., \& Cole, A. (1996). Peer Relationships and Preadolescents’ Perceptions of Security in the Child-Mother Relationship. Developmental Psychology, 32, 457-466. http://dx.doi.org/10.1037/0012-1649.32.3.457

Lazarus, R. S. (2000). Estrés y emoción. Manejo e implicaciones en nuestra salud [Stress and Emotion. Management and Implications on Our Health]. Bilbao: Desclée de Brouwer.

Lemos, V. (2005). Construcción y validación de una escala para la evaluación de la deseabilidad social infantil (EDESI) [Construction and Validation of a Scale to Assess Social Desirability in Children (EDESI). Interdisciplinaria, 22, 77-96.

Levav, M. (2005). Neuropsicología de la emoción. Particularidades en la infancia [Neuropsychology of Emotion. Special Features in Childhood]. Revista Argentina de Neuropsicología, 5, 15-24. 
Lyubomirsky, S. (2007). The How of Happiness. New York: The Penguin Press.

Lyubomirsky, S., \& Lepper, H. S. (1999). A Measure of Subjective Happiness: Preliminary Reliability and Construct Validation. Social Indicators Research, 46, 137-155. http://dx.doi.org/10.1023/A:1006824100041

MacDonald, P. M., \& Kirkpatrick, S. W. (1996). Schematic Drawings of Facial Expressions for Emotion Recognition and Interpretation by Preschool-Age Children. Genetic, Social \& General Psychology Monographs, 122, 375-388.

Martín, A. F., Avero, P., \& Gutiérrez Calvo, M. (2012). A Smile Makes the Eyes Look Happy. Escritos de Psicología, 5, 2533.

Martínez Arias, R. (1995). Psicometría: Teoría de los tests psicológicos y educativos [Psychometrics: Theory of Psychological and Educational Tests]. Madrid: Síntesis Psicología.

Matson, J., Rotatori, A., \& Helsel, W. (1983). Development of a Rating Scale to Measure Social Skills in Children: The Matson Evaluation of Social Skills with Youngsters (MESSY). Behaviour Research and Therapy, 21, 335-340. http://dx.doi.org/10.1016/0005-7967(83)90001-3

Matsumoto, D., Keltner, D., Shiota, M. N., O’Sullivan, M., \& Frank, M. (2008). Facial Expressions of Emotion. In M. Lewis, J. M. Haviland-Jones, \& L. F. Barrett (Eds.), Handbook of Emotions (3rd ed., pp. 211-234). New York: Guilford Press.

Merrell, K., \& Gimpel, G. (1998). Social Skills of Children and Adolescents. Conceptualization, Assessment, Treatment. Mahwah, NJ: Lawrence Erlbaum Associates.

Michelson, L., Sugai, D., Wood, R., \& Kazdin, A. (1987). Las habilidades sociales en la infancia [Social Skills in Childhood]. Barcelona: Martínez Roca.

Montgomery, S. A., \& Asberg, M. (1979). A New Depression Scale Designed to Be Sensitive to Change. The British Journal of Psychiatry, 134, 382-389. http://dx.doi.org/10.1192/bjp.134.4.382

Miró, J., \& Huguet, A. (2004). Evaluation of Reliability, Validity, and Preference for a Pediatric Pain Intensity Scale: The Catalan Version of the Faces Pain Scale-Revised. Pain, 111, 59-64. http://dx.doi.org/10.1016/j.pain.2004.05.023

Niedenthal, P. M., Mermillod, M., Maringer, M., \& Hess, U. (2010). The Simulation of Smiles (SIMS) Model: Embodied Simulation and the Meaning of Facial Expression. Behavioral and Brain Sciences, 33, 417-433.

http://dx.doi.org/10.1017/S0140525X10000865

Nogales, A. M. (1997). Evaluación estructurada de la personalidad [Structured Assessment of Personality]. Madrid: Pirámide.

Oliva, A. (2006). Relaciones familiares y desarrollo adolescente [Family Relationships and Adolescent Development]. Anuario de Psicología, 37, 209-223.

Oros, L. (2006). Aplicación Piloto de un Programa de Promoción de Emociones Positivas en un grupo de ni-os en riesgo ambiental [Pilot Implementation of a Program to Promote Positive Emotions in a Group of Children at Environmental Risk]. First Latin American Conference on Positive Psychology, University of Palermo, Buenos Aires.

Oros, L. B. (2008). Avances metodológicos en evaluación de emociones positivas en ni-os en riesgo social [Methodological Advances in the Assessment of Positive Emotions in Children at Social Risk]. Revista Evaluar, 8, 20-33.

Oros, L. B. (2009). Impacto de una intervención continua para estimular las emociones positivas en ni-os y ni-as afectados por la pobreza [The Impact of a Continued Intervention to Stimulate Positive Emotions in Children Affected by Poverty]. In M. C. Richaud de Minzi, \& J. E. Moreno (Eds.), Recientes desarrollos iberoamericanos en investigación en Ciencias del Comportamiento [Latest Developments in Latin American Research in the Behavioral Sciences] (pp. 243-255). Buenos Aires: CIIPME.

Oros, L. B. (2013). ¿Cómo evaluar la alegría en la infancia? Utilidad y funcionamiento de una escala pictórica [How to Assess Joy in Childhood. Utility and Operation of a Pictorial Scale]. Technical Report PRI2-2013, Misiones: Research Department, Instituto Superior Adventista de Misiones.

Oros, L. B. (2014). Nuevo cuestionario de emociones positivas para niños [New Questionnaire for Children of Positive Emotions]. Anales de Psicología, 30, 522-529. http://dx.doi.org/10.6018/analesps.30.2.158361

Oros, L., \& Greco, C. (2009). ¿A qué atribuyen la alegría los ni-os de contextos urbano-marginales? Un estudio comparativo [To What Things Do Children from Marginal Urban Contexts Attribute Joy? A Comparative Study]. The XXXII Interamerican Congress of Psychology, Interamerican Society of Psychology, Guatemala City.

Oros, L. B., Manucci, V., \& Richaud de Minzi, M. C. (2011). Desarrollo de emociones positivas en la niñez. Lineamientos para la intervención escolar [Development of Positive Emotions in Childhood. Guidelines for School Intervention]. Educación y Educadores, 14, 493-509. http://dx.doi.org/10.5294/edu.2011.14.3.3

Oros, L. B., Vargas Rubilar, J., \& Krumm, G. (2014). Parentalidad y emociones positivas durante la niñez [Parenting and Positive Emotions during Childhood]. Acta Psiquiátrica y Psicológica de América Latina, 60, 25-35.

Platt, T., Hofmann, J., Ruch, W., \& Proyer, R. T. (2013). Duchenne Display Responses toward Sixteen Enjoyable Emotions: Individual Differences between No and Fear of Being Laughed at. Motivation and Emotion, 37, 776-786. 
http://dx.doi.org/10.1007/s11031-013-9342-9

Pons, F., \& Harris, P. L. (2005). Longitudinal Change and Longitudinal Stability of Individual Differences in Children's Emotion Understanding. Cognition \& Emotion, 19, 1158-1174. http://dx.doi.org/10.1080/02699930500282108

Pons, F., Harris, P. L., \& de Rosnay, M. (2004). Emotion Comprehension between 3 and 11 Years: Developmental Periods and Hierarchical Organization. European Journal of Developmental Psychology, 1, 127-152. http://dx.doi.org/10.1080/17405620344000022

Pons, F., Lawson, J., Harris, P. L., \& de Rosnay, M. (2003). Individual Differences in Children's Emotion Understanding: Effects of Age and Language. Scandinavian Journal of Psychology, 44, 347-353. http://dx.doi.org/10.1111/1467-9450.00354

Richaud de Minzi, M. C. (2002). Inventario acerca de la percepción que tienen los niños y las niñas de las relaciones con sus padres y madres: Versión para 4 a 6 años [Inventory on Children's Perception about Their Relationships with Their Parents: Version for 4-6 Years]. Revista Interamericana de Psicología, 36, 149-165.

Richaud de Minzi, M. C. (2005). Teoría de la medición y teoría psicológica: Su articulación en los tests [Measurement Theory and Psychological Theory: Their Articulation in Test]. Suma Psicológica, 12, 7-22.

Richaud de Minzi, M. C. (2007). La percepción de estilos de relación con su padre y madre en niños y niñas de 8 a 12 años [Perception of Styles of Relationship with Parents in Children Aged 8-12 Years]. Revista Iberoamericana de Evaluación Psicológica, 1, 63-81.

Richaud de Minzi, M. C., Sacchi, C., \& Moreno, J. E. (2001). Desarrollo de resiliencia en niños en riesgo ambiental por pobreza extrema [Development of Resilience in Children at Environmental Risk Due to Extreme Poverty]. Technical Report PICT 99/04-06300, Buenos Aires: CIIPME-CONICET.

Segrin, C., \& Taylor, M. (2007). Positive Interpersonal Relationships Mediate the Association between Social Skills and Psychological Well-Being. Personality and Individual Differences, 43, 637-646. http://dx.doi.org/10.1016/j.paid.2007.01.017

Schulz Begle, A. (2009). Correlatos emocionales y relacionales de las habilidades sociales en los niños argentinos [Emotional and Relational Correlates of Social Skills in Argentine Children]. In M. C. Richaud de Minzi (Ed.), Investigación en Ciencias del Comportamiento: Avances Iberoamericanos (pp. 351-379). Buenos Aires: CIIPME-CONICET.

Schulz Begle, A. (2012). Habilidades sociales como recursos psicológicos durante la ni-ez: Su relación con las prácticas parentales, las emociones positivas y negativas y los estilos de afrontamiento [Social Skills as a Psychological Resource during Childhood, Its Relation to Parenting Practices, Positive and Negative Emotions and Coping Styles]. Doctoral Thesis, San Luis: Universidad Nacional de San Luis.

Schulz Begle, A., Lemos de Ciuffardi, V., \& Richaud de Minzi, M. C. (2009). Validación de la Positive Affect and Negative Affect Schedule versión niños (PANAS-C) en la población infantil argentina [Validation of the Positive Affect and Negative Affect Schedule-child form (PANAS-C) in Argentine children]. XXXII Interamerican Congress of Psychology, Guatemala City, 28 June-2 July 2009.

Stifter, C. A., \& Fox, N. A. (1986). Preschool Children’s Ability to Identify and Label Emotions. Journal of Nonverbal Behavior, 10, 255-266. http://dx.doi.org/10.1007/BF00987483

Trianes, M., Blanca, M., Muñoz, A., García, B., Cardelle-Elawar, M., \& Infante, L. (2002). Relaciones entre evaluadores de la competencia social en preadolescentes: Profesores, iguales y autoinformes [Relationship among Assessors of Social Competence in Preadolescents: Teachers, Peers and Self-Reports]. Anales de Psicología, 18, 197-214.

Vaughan Sallquist, J., Eisenberg, N., Spinrad, T., Reiser, M., Hofer, C., Zhou, Q., Liew, J., \& Eggum, N. (2009). Positive and Negative Emotionality: Trajectories accross Six Years and Relations with Social Competence. Emotion, 9, 15-28. http://dx.doi.org/10.1037/a0013970

Wang, Q., Pomerantz, E. M., \& Chen, H. (2007). The Role of Parents’ Control in Early Adolescents’ Psychological Functioning: A Longitudinal Investigation in the United States and China. Child Development, 78, 1592-1610. http://dx.doi.org/10.1111/j.1467-8624.2007.01085.x

Ware, L. J., Epps, C. D., Herr, K., \& Packard, A. (2006). Evaluation of the Revised Faces Pain Scale, Verbal Descriptor Scale, Numeric Rating Scale, and Iowa Pain Thermometer in Older Minority Adults. Pain Management Nursing, 7, 117125. http://dx.doi.org/10.1016/j.pmn.2006.06.005

Watson, D. (2005). Positive Affectivity: The Disposition to Experience Pleasurable Emotional States. In R. Snyder, \& S. J. Lopez (Eds.), Handbook of Positive Psychology (pp. 106-119). New York: Oxford University Press.

Widen, S. C., \& Russell, J. A. (2008). Children Acquire Emotion Categories Gradually. Cognitive Development, 23, $291-312$. http://dx.doi.org/10.1016/j.cogdev.2008.01.002

Wong, D. L., \& Baker, C. M. (1988). Pain in Children: Comparison of Assessment Scales. Pediatric Nursing, 14, 9-17. 
Scientific Research Publishing (SCIRP) is one of the largest Open Access journal publishers. It is currently publishing more than 200 open access, online, peer-reviewed journals covering a wide range of academic disciplines. SCIRP serves the worldwide academic communities and contributes to the progress and application of science with its publication.

Other selected journals from SCIRP are listed as below. Submit your manuscript to us via either submit@scirp.org or Online Submission Portal.
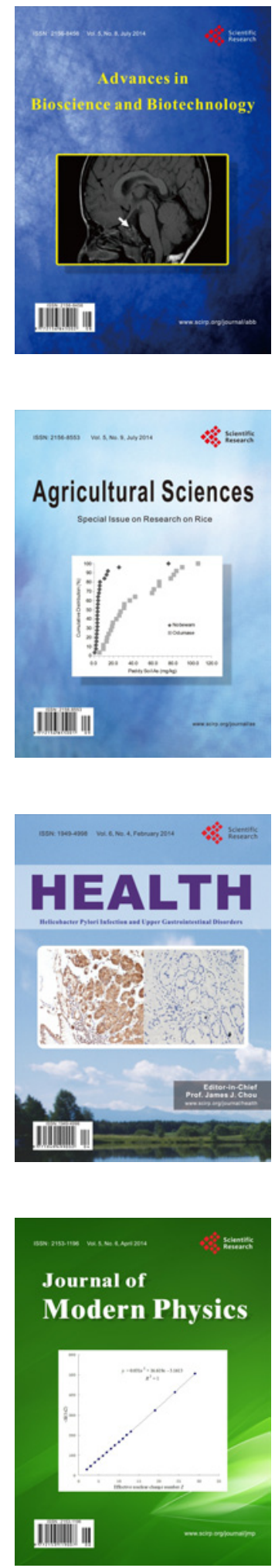
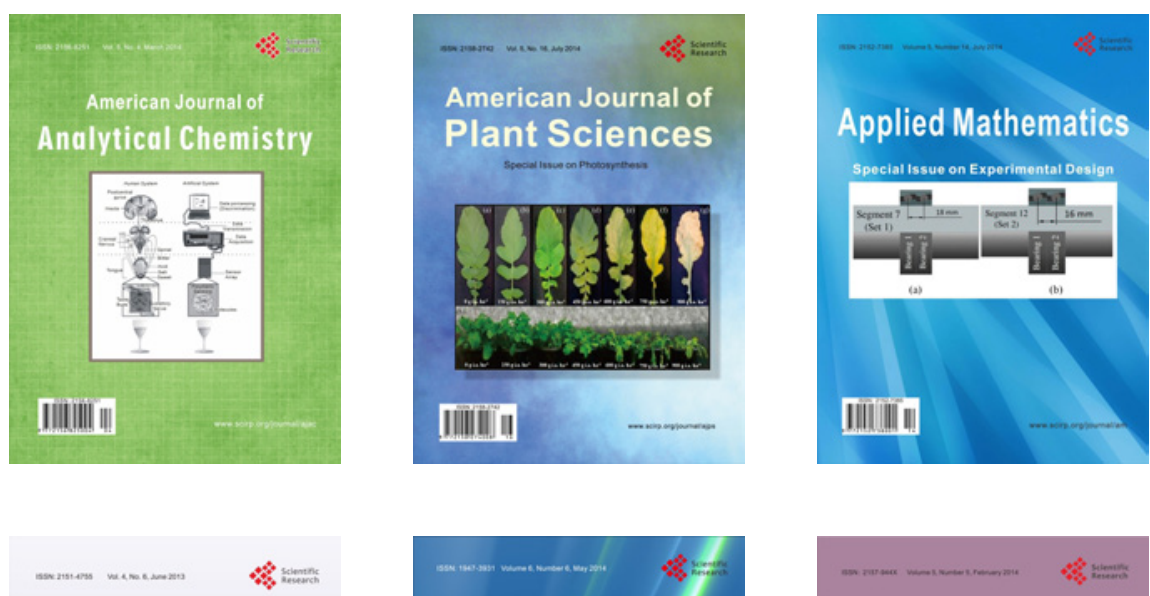

Creative Education
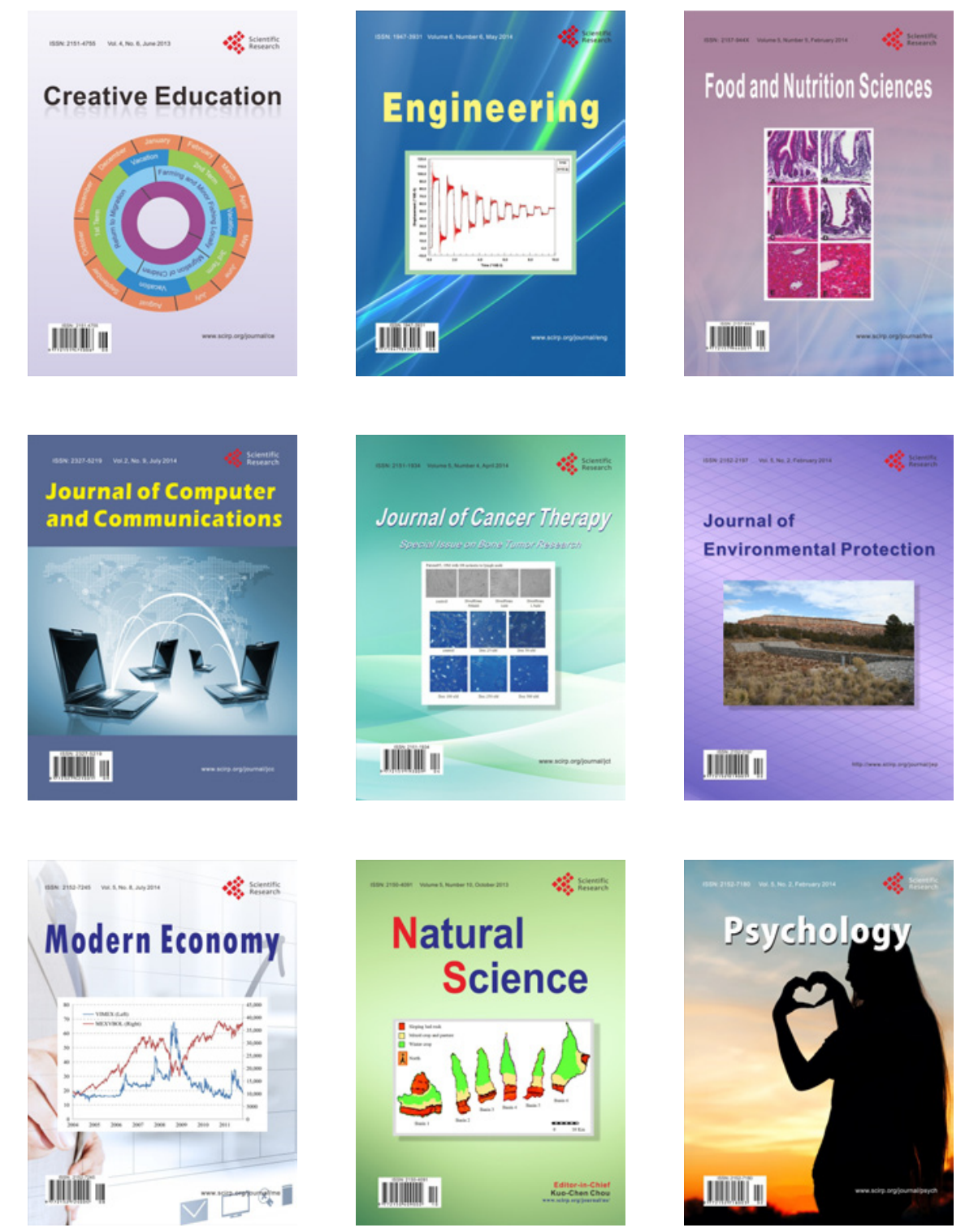